\title{
Ash-plume dynamics and eruption source parameters by infrasound and thermal imagery: The 2010 Eyjafjallajökull eruption
}

\author{
M. Ripepe ${ }^{\mathrm{a}, *}$, C. Bonadonna ${ }^{\mathrm{b}}$, A. Folch ${ }^{\mathrm{c}}$, D. Delle Donne ${ }^{\mathrm{a}}, \mathrm{G}$. Lacanna ${ }^{\mathrm{a}}$, E. Marchetti $^{\mathrm{a}}$, \\ A. Höskuldsson ${ }^{\mathrm{d}}$ \\ a Department of Earth Sciences, University of Florence, via LaPira, 4, 50121 Firenze, Italy \\ ${ }^{\mathrm{b}}$ Earth and Environmental Sciences Section, University of Geneva, Geneva, Switzerland \\ ${ }^{\mathrm{c}}$ Barcelona Supercomputing Center-Centro Nacional de Supercomputación (BSC-CNS), Barcelona, Spain \\ ${ }^{\mathrm{d}}$ Nordic Volcanological Center, Institute of Earth Sciences, University of Iceland, Reykjavik, Iceland
}

\section{A R T I C L E I N F O}

\section{Article history:}

Received 11 May 2012

Received in revised form

2 February 2013

Accepted 5 February 2013

Editor: P. Shearer

Available online 20 March 2013

\section{Keywords:}

ash eruptions

plume height

mass eruption rate

infrasound

\begin{abstract}
A B S T R A C T
During operational ash-cloud forecasting, prediction of ash concentration and total erupted mass directly depends on the determination of mass eruption rate (MER), which is typically inferred from plume height. Uncertainties for plume heights are large, especially for bent-over plumes in which the ascent dynamics are strongly affected by the surrounding wind field. Here we show how uncertainties can be reduced if MER is derived directly from geophysical observations of source dynamics. The combination of infrasound measurements and thermal camera imagery allows for the infrasonic type of source to be constrained (a dipole in this case) and for the plume exit velocity to be calculated $(54-142 \mathrm{~m} / \mathrm{s})$ based on the acoustic signal recorded during the 2010 Eyjafjallajökull eruption from 4 to 21 May. Exit velocities are converted into MER using additional information on vent diameter $(50 \pm 10 \mathrm{~m})$ and mixture density $\left(5.4 \pm 1.1 \mathrm{~kg} / \mathrm{m}^{3}\right)$, resulting in an average $\sim 9 \times 10^{5} \mathrm{~kg} / \mathrm{s}$ MER during the considered period of the eruption. We validate our acoustic-derived MER by using independent measurements of plume heights (Icelandic Meteorological Office radar observations). Acoustically derived MER are converted into plume heights using field-based relationships and a 1D radially averaged buoyant plume theory model using a reconstructed total grain size distribution. We conclude that the use of infrasonic monitoring may lead to important understanding of the plume dynamics and allows for real-time determination of eruption source parameters. This could improve substantially the forecasting of volcano-related hazards, with important implications for civil aviation safety.
\end{abstract}

(c) 2013 Elsevier B.V. All rights reserved.

\section{Introduction}

Real-time forecasting of ash dispersal strongly depends on the characterization of Eruption Source Parameters (ESP), such as plume height, Mass Eruption Rate (MER), and Total Grain Size Distribution (TGSD), which are often difficult to be provided with the necessary accuracy within the first hours of an eruption (Mastin et al., 2009). If the definition of no-fly zones based on ash concentration thresholds consolidates as an International Civil Aviation Organization (ICAO) standard product, operational ash cloud forecasting will require more precise quantifications of the ESP, and, in particular, of the MER. The 2010 Eyjafjallajökull summit eruption revealed deficiencies in the current ash cloud forecasting system (mainly assessment of model input parameters and definition of safe ash concentration thresholds), which was proved to have serious implications on the air-travel

\footnotetext{
* Corresponding author. Tel.: +39055 275 7479; fax: +39055 218628 .

E-mail address: maurizio.ripepe@unifi.it (M. Ripepe).
}

infrastructure (Miller, 2011; Ulfarsson and Unger, 2011; O'Regan, 2011). This ash-rich explosive eruption was characterized by nearly continuous injection of tephra into the atmosphere associated with long-lasting bent-over plumes, mostly dispersed toward east and southeast, reaching an average height of about $4 \mathrm{~km}$ with peaks of $8 \mathrm{~km}$ a.s.l. (Arason et al., 2011). Bent-over plumes (i.e. weak plumes) develop when the velocity of the surrounding wind is higher than the plume exit velocity. This is in contrast to strong plumes, characterized by an ascending velocity of the buoyant column larger than that of wind. Weak plumes are significantly more frequent and, when associated with long-lasting eruptions, can not only affect local communities but also cause prolonged disruptions in the global air traffic, with effects that go far beyond the direct impacts on the air transport industries (Ernst et al., 1994; Guffanti et al., 2010; Miller and Casadevall, 2000; Prata and Tupper, 2009; Rose et al., 1995; Scollo et al., 2009; O'Regan, 2011).Strong and weak plumes are characterized by significantly different dynamics (e.g., Morton et al., 1956; Briggs, 1969; Turner, 1973; Wright et al., 1984; Sparks, 1986; Carey and Sparks, 1986; Coelho and Hunt, 1989; Bursik, 
2001 ) and result in very different tephra deposits (e.g., Ernst et al., 1994, Bonadonna et al., 2005). As a result, empirical and theoretical relations that link plume height and MER for strong plumes (e.g., Wilson and Walker, 1987; Sparks, 1986; Mastin et al., 2009) cannot be easily extrapolated to weak plumes, making the realtime characterization of the source term even more complex (Degruyter and Bonadonna, 2012). In this case, geophysical monitoring of vent processes can provide an alternative characterization of the source term based on plume dynamics at the vent

Volcanic eruptions are generally associated to strongamplitude seismic tremors caused by the migration of magma through volcanic conduits, and/or by the dynamics of gas decoupled from the liquid magma (Nishimura, 1995). Detailed analyses of reduced displacements of eruption tremors at several volcanoes have revealed a linear relation between the reduced displacement of tremor and the Volcanic Explosivity Index (McNutt, 2004). However, a simple procedure to deduce general scaling relationships to estimate plume height directly from seismic signals does not exist yet (Nishimura and McNutt, 2008; Prejean and Brodsky, 2011). Tremors can actually be associated to magma intruding within the volcanic body as well as to oscillations of the magma column during the eruption. This multiplicity of tremor sources complicates the use of tremor signals as a proxy for eruption intensity (Caplan-Auerbach and McNutt, 2003). In fact, the 2010 Eyjafjallajökull eruption highlighted this difficulty since tremor amplitudes reached the highest values during the low-discharge effusive phase, from 18 April to 4 May (Sigmundsson et al., 2010; Gudmundsson et al., 2012).

In addition to seismicity, volcanic activity generates infrasonic waves (acoustic waves below $20 \mathrm{~Hz}$ ), which efficiently propagate in the atmosphere allowing the remote monitoring of volcanic activity in large areas (e.g. Matoza et al., 2011a).

Infrasound associated with explosive eruptions is generally produced by the rapid expansion of the gas-particle mixture within the conduit and, in consequence, is related to the dynamics of the volume outflow and thus to the intensity of the eruption.

Unlike seismology, infrasound is, thus, intimately linked to the magma fragmentation process and, in general, to any other phenomenon well coupled with the atmosphere (any source inducing a volume change in the atmosphere is a potential producer of infrasonic waves). For this reason, in the last decades, volcano acoustics is slowly becoming a reality in monitoring procedures also at a local scale (see Johnson and Ripepe, 2011, for a review).

The CTBTO (Comprehensive Nuclear-Test-Ban Treaty Organisation) International Monitoring System (IMS) infrasonic network (Campus and Christie, 2010) operating since early 2000 has shown how efficient the modern infrasound technology is in detecting small pressure perturbation $(<0.01 \mathrm{~Pa})$ generated by moderate (VEI $>2$ ) volcanic activity (e.g. Le Pichon et al., 2005) also at large distances up to $9000 \mathrm{~km}$ (Dabrowa et al., 2011). The ash-plume activity of the volcano Ejyafjallajokull in Iceland was detected by the IMS stations in Europe, Russia and North Africa up to a distance of $3600 \mathrm{~km}$ (Matoza et al., 2011b). From the sole monitoring point of view, during a volcanic eruption, infrasound provides information on the location of the source processes and intensity of the eruption, and gives direct and rapid evidence on the variations of the explosive activity.

In this paper we discuss the real-time evaluation of MER and plume height using infrasonic array at local distance $(<10 \mathrm{~km})$. We analyze the potential of this methodology as a reliable alternative for a better characterization of relevant ESP, especially for eruptions associated with weak plumes, such as those produced during the Eyjafjallajökull 2010 eruption.
First we summarize the characteristics of the infrasonic monitoring (Section 2) and the thermal camera (Section 3) deployed at Eyjafjallajökull during 4-21 May, 2010. Section 4 discusses how ESP can be estimated by acoustic pressure. An indirect validation of the methodology, comparing radar plume height measurements with heights calculated from the acousticderived MER, is presented in Section 5. Finally, we conclude with a discussion on the implications for real-time evaluation of ESP.

\section{Infrasonic monitoring at Eyjafjallajökull}

We recorded the ash plume activity of Eyjafjallajökull using a 4-element infrasonic array with a triangular geometry and an aperture (maximum distance between two elements) of $\sim 120 \mathrm{~m}$ (EJA in Fig. 1A and B). The array was installed in Thorvaldseyri, south of Eyjafjallajökull, at a distance of $\sim 8.3 \mathrm{~km}$ from the craters. Each array element was equipped with differential pressure transducer with a sensitivity of $25 \mathrm{mV} / \mathrm{Pa}$ in the frequency band $0.001-50 \mathrm{~Hz}$ and a noise level of $10^{-2} \mathrm{~Pa}$ (Marchetti et al., 2009). These sensors were chosen for their wide frequency band, good pressure sensitivity, and low power requirement $(\sim 60 \mathrm{~mW})$. All the array elements were connected to the central station and acoustic data were digitized using a 24 bits Guralp CMG-DM24 at the sampling rate of $100 \mathrm{~Hz}$, and recorded both on site and transmitted via Internet link to the Icelandic Meteorological Office (IMO). Time synchronization was achieved with a GPS receiver. A second acoustic station (YHL in Fig. 1A) equipped with the same differential pressure transducer and acquisition system was temporally deployed eastward of the crater at a distance of $\sim 10.6 \mathrm{~km}$.

Location of the infrasonic source is performed by array multichannel semblance analysis applied on a grid-searching procedure (Ripepe and Marchetti, 2002) to identify signals from noise in terms of propagation back-azimuth and apparent velocity. For a $120 \mathrm{~m}$ aperture array the expected azimuth resolution is $<2^{\circ}$ (Ulivieri et al., 2011), which corresponds to $\sim 250 \mathrm{~m}$ at a slant distance of $8300 \mathrm{~m}$.

The array data processing shows that most of the acoustic activity came from a back-azimuth direction of $\sim 5^{\circ} \mathrm{N}$, consistent with the position of the erupting crater during the last phase of the Eyjafjallajökull eruption (Fig. 2). The peak excess pressure of the signals associated with this back-azimuth shows how the activity at the crater was quite high during the first week of May

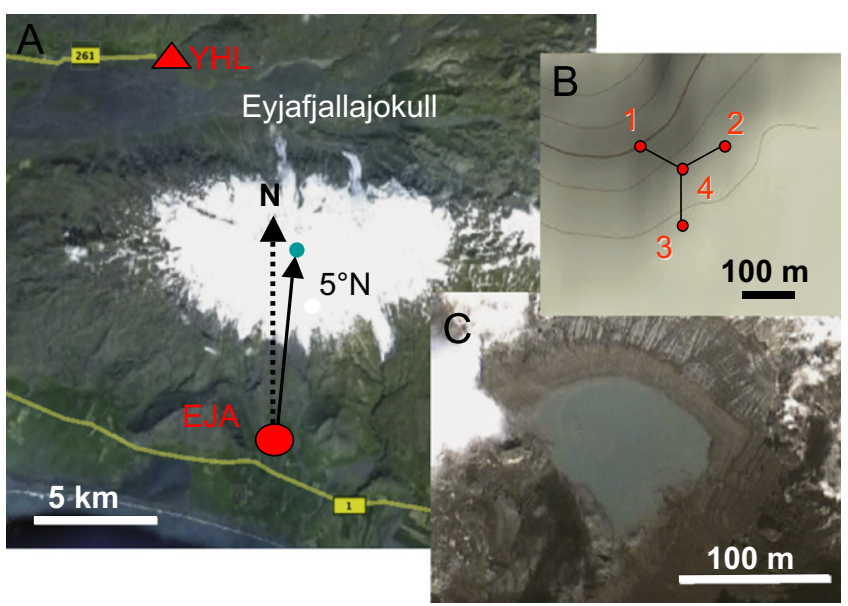

Fig. 1. (A) Map with the position of the array EJA and the acoustic station YHL. The array (B) has a triangle geometry with an aperture of $120 \mathrm{~m}$ and a distance of $\sim 8.3 \mathrm{~km}$ from the crater. (C) Satellite image of the lake formed in 2011 inside the active crater which has a diameter of $\sim 70 \mathrm{~m}$ and is oriented at $5^{\circ} \mathrm{N}$ from the array. 
a
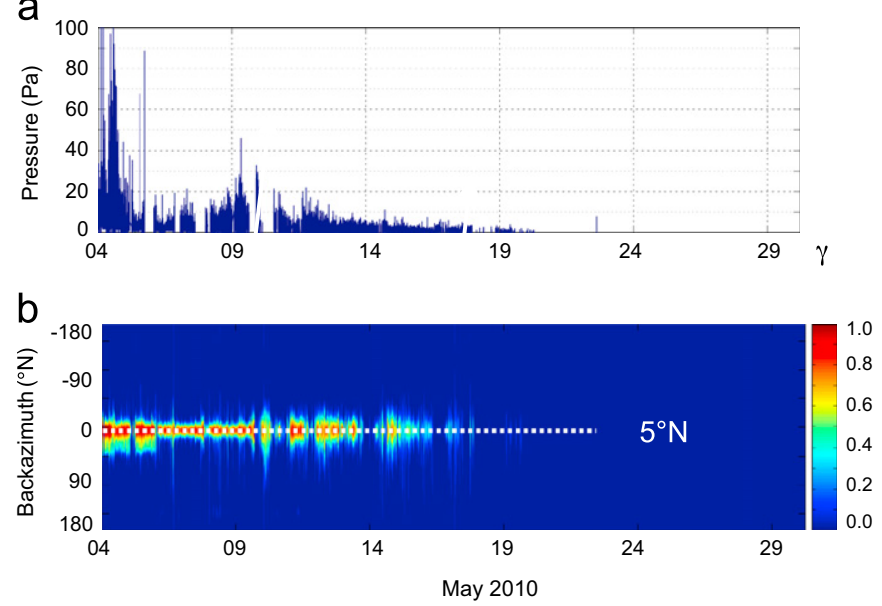

Fig. 2. (a) Acoustic pressure (Pa) detected by the array after May 4, 2010. Acoustic pressure was very high at the beginning of May, reaching amplitudes of $\sim 105 \mathrm{~Pa}$, which if reduced at $1 \mathrm{~m}$ from the source are equivalent to $870 \mathrm{kPa}(\sim 10$ times the atmospheric pressure at $1550 \mathrm{~m}$ of elevation). (b) The back-azimuth analysis indicates an infrasonic activity coming from an average azimuth of $5^{\circ} \mathrm{N}$, a direction consistent with the position of the vent (see Fig. 1). Color bar indicates the amplitude of the semblance $(\gamma)$ function. (For interpretation of the references to color in this figure legend, the reader is referred to the web version of this article.)

and that it slowly declined after May 6th. The amplitude evolution of the excess pressure evidences very strong activity from 4th to 6th May, which gradually decreased until May 21th. After that, no more acoustic signals are recorded from the back-azimuth direction of $5^{\circ} \mathrm{N}$ indicating that explosive activity at the vent ceased. This acoustic evidence is consistent with the visual monitoring of the activity, which indicates the end of activity at the vent on May 21 (Gudmundsson et al., 2012).

\section{Thermal infrared camera at Eyjafjallajökull}

Thermal images were collected on 4th May, 2010, for a period of 2.5 hours at a rate of $10 \mathrm{~Hz}$ using a FLIR-A20 thermal camera deployed at a distance of $\sim 8.3 \mathrm{~km}$ from the vent in the same location of the infrasonic array (Fig. 1A). The camera is sensitive to thermal infrared radiation emitted in the $7.5-13 \mu \mathrm{m}$ waveband with a maximum thermal resolution of $0.1^{\circ} \mathrm{C}$, and samples the $34^{\circ} \times 25^{\circ}$ field of view with a $320 \times 240$ pixel image, which at a slant distance of $\sim 8.3 \mathrm{~km}$ coincides with a scenery $5.0 \times 3.6 \mathrm{~km}$ large (Fig. 3a). The temporal evolution of the ascending plume can be traced using image analysis with a resolution of $\pm 15 \mathrm{~m}$, providing a detailed description of the plume dynamics in terms of plume height, shape and leading edge velocity. The temperature gradient between the plume and the background is characterized by a sharp contrast that makes the plume leading edge easy to be tracked using the most external thermal isoline. Plume velocity with a resolution of $\sim 3 \%$ can be calculated by the thermal decomposition method using multiple thermal contour lines (Delle Donne and Ripepe, 2012).

The analysis reveals that the Eyjafjallajökull plume was sustained by a series of single thermal puffs of hot gases and ash (Fig. 3a). The height of each single ash-puff was measured by stacking, along the horizontal axis, the temperature of the vertical lines crossing the eruptive vent in the thermal images. History of ash-puffing height was derived by piling up, in time, the stacked temperature. This is a simple but effective method for tracking heights of single puffs in real time (Fig. $3 \mathrm{~b}$ ). Each puff reached an elevation ranging between 100 and $600 \mathrm{~m}$ above the visible vent horizon (Fig. 3c).

According to thermal imagery analysis, each puff was characterized by a short initial velocity peak $<150 \mathrm{~m} / \mathrm{s}$ lasting $\sim 1.5 \mathrm{~s}$ a
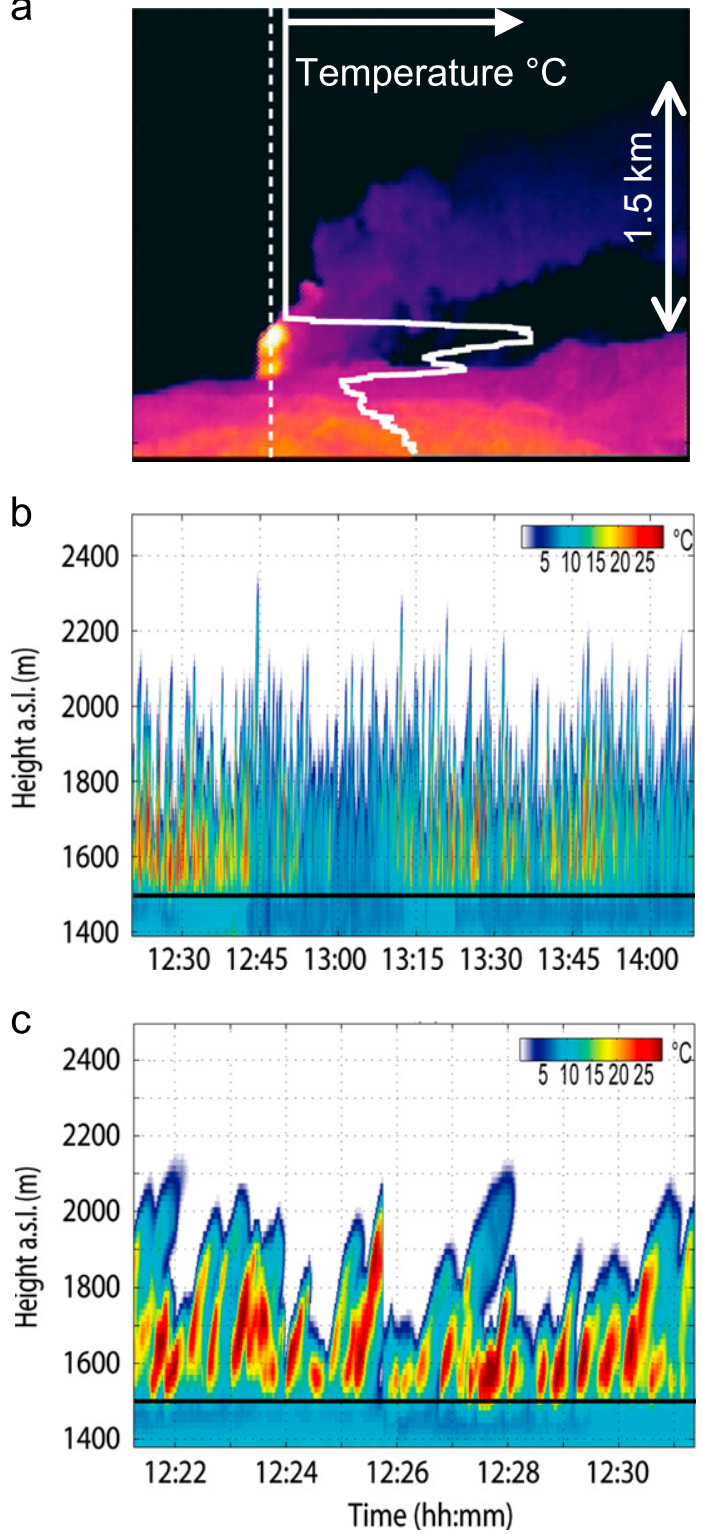

Fig. 3. (a) On May 4 the ash-plume activity was recorded by thermal cameras. The thermal images have been used to derive the plume activity near the vent by thermal decomposition . (b) Thermal processing of $\sim 2.5 \mathrm{~h}$ of ash-plume activity on May 4, 2010 shows that the plume is sustained by thermal puffs reaching an altitude of 2000-2300 m a.s.l. (c) Thermals of hot puffs are repeating every $\sim 20 \mathrm{~s}$ and the hot core of the puffs is extending to an elavation of $100-500 \mathrm{~m}$ above the crater level (indicated by the black line at $1550 \mathrm{~m}$ ).

followed by a smooth velocity decrease down to typical buoyancy velocities of $\sim 10 \mathrm{~m} / \mathrm{s}$ (Fig. $4 \mathrm{~b}$ and $\mathrm{c}$ ). Image analysis shows also that plume puffs occurred at a mean period of $\sim 20 \mathrm{~s}$ and having average velocities of $\sim 45 \mathrm{~m} / \mathrm{s}$ (Fig. 5). This oscillatory behavior of the plume has its origin in conduit flow dynamics and is the most probable cause for the acoustic wave field below $0.1 \mathrm{~Hz}$ (Fig. 6) that characterizes the spectra of the infrasound recorded at Eyjafjallajökull by the array and by the acoustic station.

\section{ESP from infrasound and thermal camera measurements}

\subsection{Plume exit velocities}

The link between acoustic pressure and the exit plume velocity has experimental evidence (Ripepe et al., 2002; Johnson, 2007; 
a
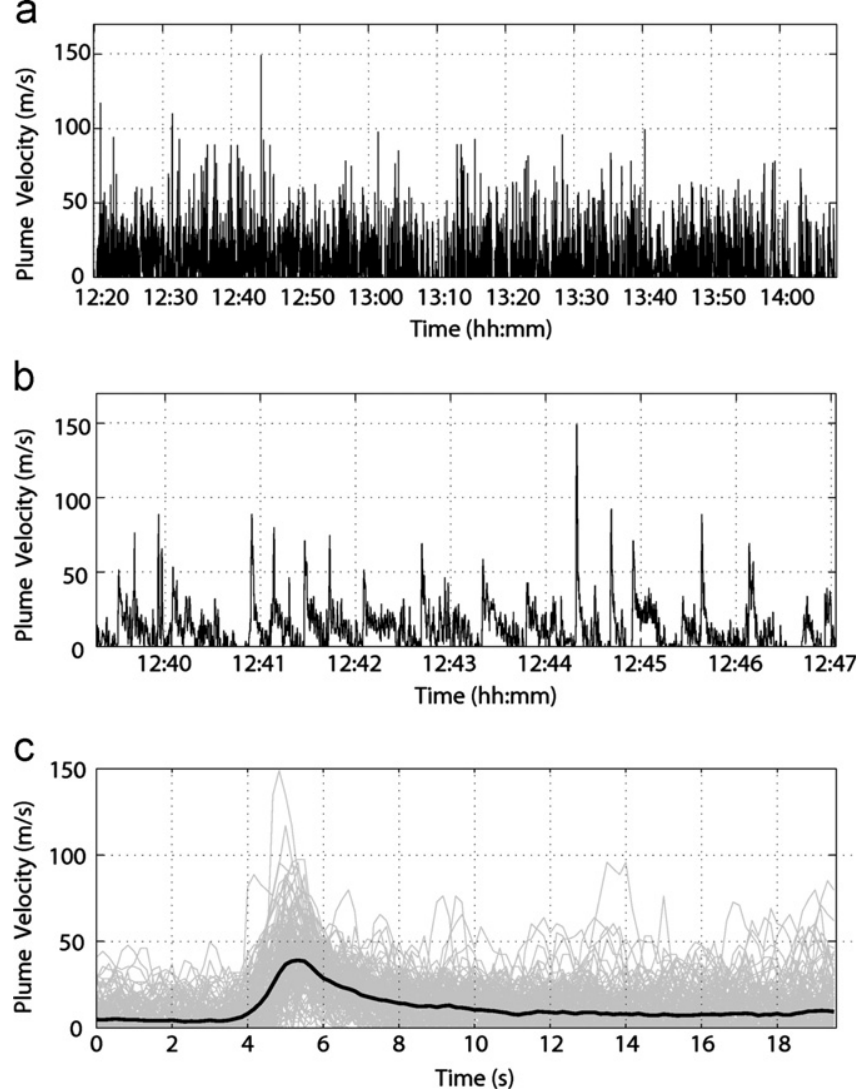

Fig. 4. (a) Thermal decomposition method of the $\sim 2.5 \mathrm{~h}$ long imagery recorded at $10 \mathrm{~Hz}$ frame rate allows to measure plume exit velocities ranging between 20 and $150 \mathrm{~m} / \mathrm{s}$ and (b) characterized by bursts of high velocity, which repeat at $20 \mathrm{~s}$ rate. (c) The ash-plume is sustained by thermal puffs (gray lines) characterized (solid black line) by a short initial velocity peak lasting $\sim 1.5 \mathrm{~s}$ followed by a smooth velocity decrease down to typical buoyancy velocities of $\sim 10 \mathrm{~m} / \mathrm{s}$.

Delle Donne and Ripepe, 2012) and it is explained by the linear theory of sound (Woulff and McGetchin, 1976; Vergniolle et al., 1996; Vergniolle and Caplan-Auerbach, 2006). For a point source, the acoustic pressure $p(t)$ in a half-space at a distance $r$ is given by (Lighthill, 1978)

$p(t)=\frac{\rho_{\text {air }}}{2 \pi r} \dot{q}(t)$

where $q(t)=S u$ is the outflow volume rate from a source of area $S$ at a velocity $u$ and $\rho_{\text {air }}$ is the density of the atmosphere. When the surface of magma deforms and expands, it produces an equivalent displacement of the atmosphere inducing a volumetric compression and generating an excess of pressure that mimics the rate of volumetric change of the source. Eq. (1) is valid for a point source expanding (or oscillating) in a three-dimensional free space. In the far-field conditions (i.e. for acoustic wavelength much larger than source dimension), the linear theory of sound demonstrates that acoustic pressure can be related to the velocity $u$ assuming a monopole, dipole or quadrupole source of sound (Lighthill, 1978). From a volcanology point of view, the monopole source is representing the spherical expansion of an explosive point source. The dipole source can be explained as the interaction of the gas jet with the solid boundary of the conduit, generating a more directional acoustic radiation lobe (Vergniolle and CaplanAuerbach, 2006). Finally, a quadrupole source of sound is the best representation for a momentum-driven turbulent free-shear jet flow, characteristic of sub-Plinian and Plinian eruptions (Matoza et al., 2009).
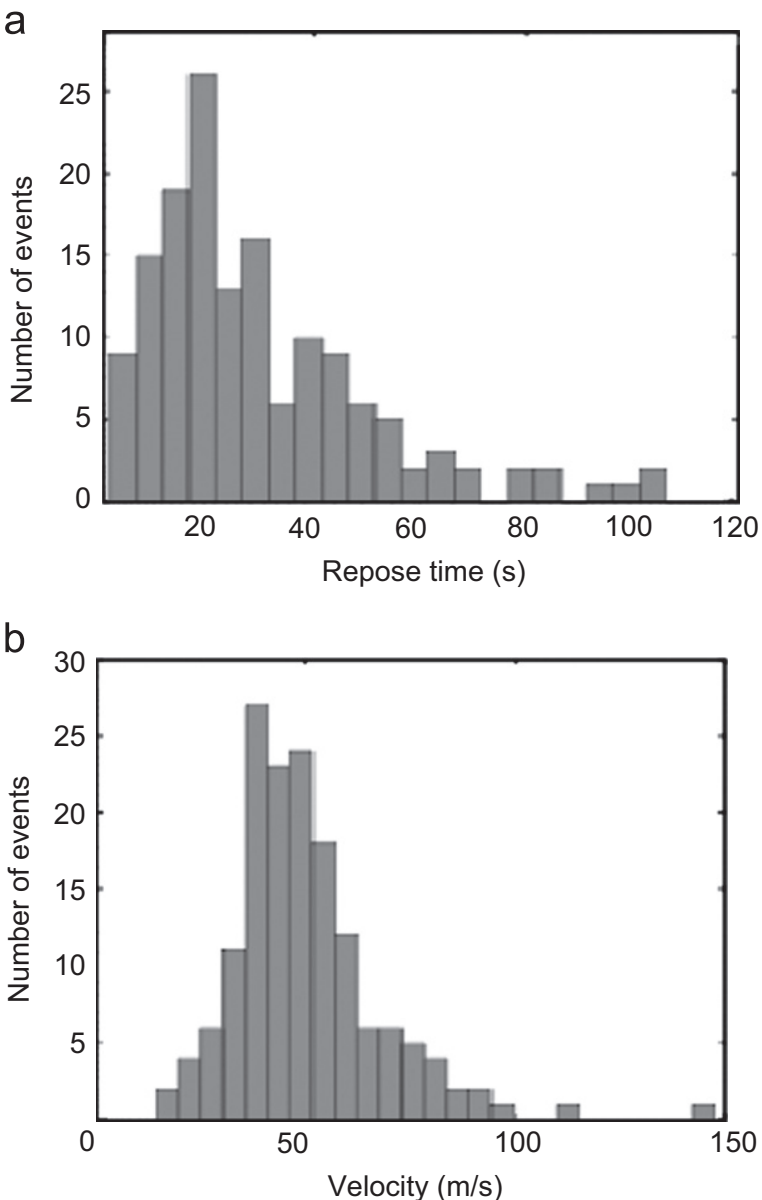

Fig. 5. Statistics of the thermal puffs in the ash-plume on 4th May (4 hours period). (a) Occurrence rate has a mean value at $\sim 20 \mathrm{~s}$. (b) Puff exit velocity, ranging between 20 and $150 \mathrm{~m} / \mathrm{s}$, with an average value of $45 \mathrm{~m} / \mathrm{s}$.

Following the source model theory, the amplitude of the first positive acoustic pressure peak $(\langle p\rangle)$ of each single infrasonic event recorded at a distance $r$ can be related to the velocity $u$ of the volumetric expansion of a source with radius $R$ by (Vergniolle and Caplan-Auerbach, 2006; Delle Donne and Ripepe, 2012)

$$
\begin{aligned}
& \langle p\rangle=\frac{\rho_{\text {air }} R \sqrt{K_{m}}}{r} u^{2} \\
& \langle p\rangle=\frac{\rho_{\text {air }} R \sqrt{K_{d}}}{r c} u^{3} \\
& \langle p\rangle=\frac{\rho_{\text {air }} R \sqrt{K_{q}}}{r c^{2}} u^{4}
\end{aligned}
$$

where $c$ is the speed of sound in the atmosphere $(334 \mathrm{~m} / \mathrm{s}$ at ambient temperature of $\left.5{ }^{\circ} \mathrm{C}\right), r$ is the distance $(8300 \mathrm{~m}$ ) between the array and the crater, and $K_{m}, K_{d}$ and $K_{q}$ are empirical constants equal to $1,10^{-2}$ and $10^{-5}$, for the monopole (2a), dipole ( $2 \mathrm{~b}$ ) and quadrupole (2c) sources respectively (Vergniolle and CaplanAuerbach, 2006). Using the expressions above and assuming that the source radius $R$ is equivalent to the mean radius of the vent $(25 \pm 5 \mathrm{~m})$ visible from satellite images (Fig. 1c), we calculated the expansion velocity $u$ of the source volume within the conduit considering the three possible acoustic source models (Fig. 7). As expected, the computed velocity covers different ranges depending on the source model.

Plume dynamics has been previously modeled as an acoustic dipole (Vergniolle and Caplan-Auerbach, 2006; Caplan-Auerbach 
a

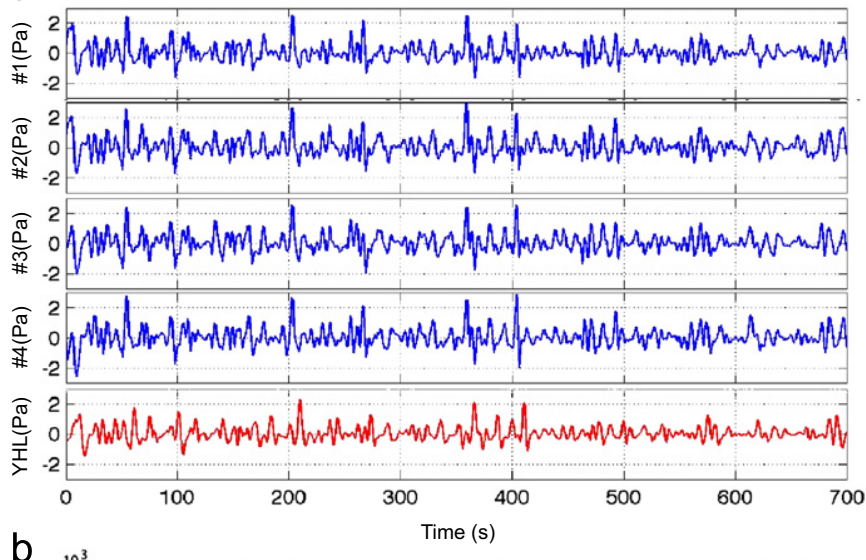

b

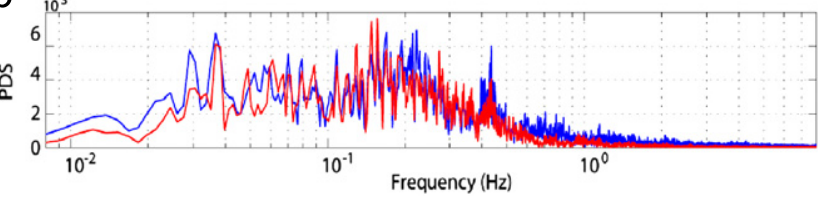

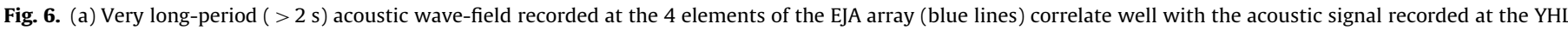

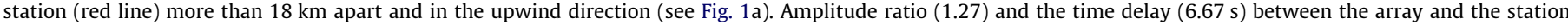
indicate that the source coincides with the crater. (b) Spectral analysis shows that the acoustic wavefield is coherent in the low-period range between $2 \mathrm{~s}$ and $50 \mathrm{~s}$

et al., 2009), but for the Eyjafjallajökull eruption we have no acoustic evidence to support one single source model and, therefore, to decide among the three equations (2a, 2b, 2c). We then consider that the velocity $u$ derived by infrasound is representing the initial velocity of the gas/particles within the conduit. Following this concept, the acoustic-derived velocities should compare or equal the exit plume velocity at the vent (Delle Donne and

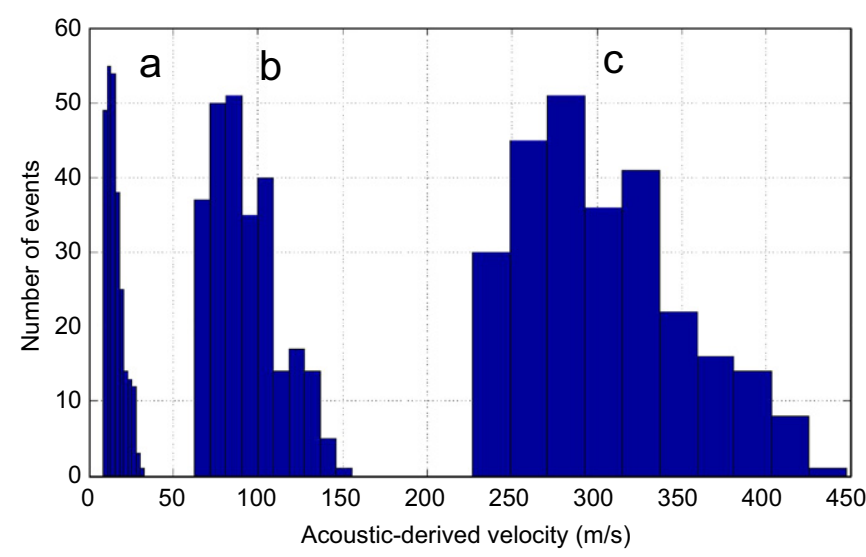

Fig. 7. Exit plume velocities calculated from acoustic pressure (see Fig. 2a) assuming (a) monopole, (b) dipole, and (c) quadrupole source models. The dipole source model gives velocities within the same range of the thermal analysis (Fig. 5b).

Ripepe, 2012). We, thus, constrain the possible acoustic source based on the thermal camera data and assume that the plume velocity measured by thermal camera represents the lower limit of the acoustic-derived velocity of the volumetric source in the conduit. Thermal camera imagery then suggests that the sound associated with the Eyjafjallajökull ash plume dynamics is more consistent with the dipole source.

The monopole source, in fact, gives velocities (Fig. 7a) within the conduit ranging between 8 and $25 \mathrm{~m} / \mathrm{s}$ (average of $12 \mathrm{~m} / \mathrm{s}$ ), which are much lower than the velocities of the plume ( $\sim 20-$ $150 \mathrm{~m} / \mathrm{s}$, see Fig. 5b) outside the conduit calculated by thermal camera analysis. On the other hand, the quadrupole source model gives too high acoustic source velocities (Fig. 7c), between 180 and $390 \mathrm{~m} / \mathrm{s}$ (average $230 \mathrm{~m} / \mathrm{s}$ ). In contrast, for the dipole source, we found (Fig. 7b) acoustic velocities of $54-152 \mathrm{~m} / \mathrm{s}$ (average $74 \mathrm{~m} / \mathrm{s}$ ) in better agreement with the plume velocities calculated by thermal camera image analysis. The acoustic source velocity $u$ for a dipole can be computed from Eq. (2b) (also in real-time) directly from the maximum amplitude of the acoustic pressure as

$u=2.154\left(\frac{r c\langle p\rangle}{\rho_{\text {air }} R}\right)^{1 / 3}$

where $\rho_{\text {air }}$ is the air density $\left(1.05 \mathrm{~kg} / \mathrm{m}^{3}\right.$ at $1550 \mathrm{~m}$ a.s.l.), $R$ is the source radius and $r$ the distance at which acoustic pressure is measured ( $8.3 \mathrm{~km}$ in our case).

\subsection{Mass eruption rate}

For a cylindrical conduit of radius $R_{v}$ the mass flux $Q(t)$ can be calculated as

$Q(t)=\pi \rho_{p} R_{v}^{2} u_{p}(t)$

which is equivalent to an instantaneous MER and where $R_{v}$ is the radius of the vent $(25 \pm 5 \mathrm{~m}), \rho_{p}$ is the mixture density, and $u_{p}$ is the plume exit velocity. Considering a range of gas content between $2 \%$ and 3\% (Borisova et al. 2012), a gas density of $0.13 \mathrm{~kg} / \mathrm{m}^{3}$, and a magma density of $2740 \mathrm{~kg} / \mathrm{m}^{3}$ (Dense Rock Equivalent; Bonadonna et al., 2011b), the resulting mixture density $\rho_{p}$ at the vent gives $5.4 \pm 1.1 \mathrm{~kg} / \mathrm{m}^{3}$.

We assume here that the acoustic velocity $u$ of the expanding surface within the conduit (Eq. 3 ) is equivalent to the plume exit velocity $\left(u=u_{p}\right)$ at the vent, as already suggested by thermal and acoustic experiments at Stromboli volcano (Delle Donne and Ripepe, 2012). Considering the source radius $R$ as the vent radius $R_{v}$ we can derive $Q(t)$ directly from the acoustic pressure (Eqs. (3) and (4)):

$Q(t)=6.768 \rho_{p} R^{1.66}\left[\langle p\rangle \frac{r c}{\rho_{\text {air }}}\right]^{1 / 3}$ 


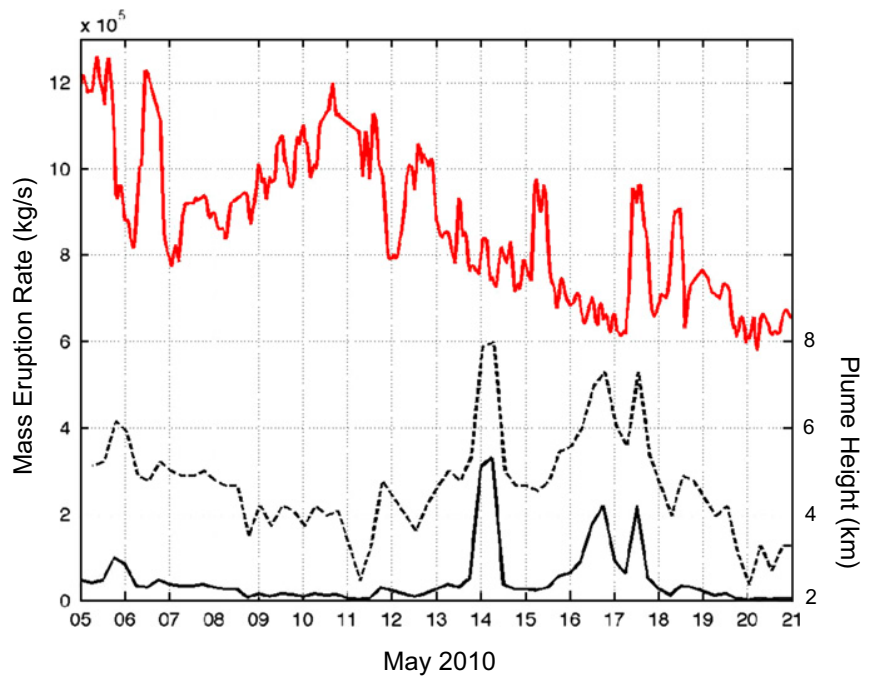

Fig. 8. Mass eruption rate (kg/s) calculated (Eq. (5)) from acoustic pressure (red upper line) considering a vent radius of $25 \mathrm{~m}$ is compared to the MER (black line) derived from the plume height (dashed black line) measured by the weather C-band Doppler radar located in Keflavik assuming the empirical Eq. (6). Acousticderived MER seems decoupled with plume height suggesting a poor correlation between acoustic pressure and eruptive intensity. In particular the plume height remains very high $(8 \mathrm{~km})$ from 14 May to 17 May while acoustic-derived MER shows minimum values of $\sim 5.7 \times 10^{5} \mathrm{Kg} / \mathrm{s}$. (For interpretation of the references to color in this figure legend, the reader is referred to the web version of this article.)

from which we calculate the $Q_{h}=\sum_{\text {hour }} Q(t)$ as the MER released in $1 \mathrm{~h}$.

Results for the time-dependent MER for the 4-21 May, 2010, period computed using plume-equivalent $\left(u=u_{p}\right)$ infrasonic velocities are shown in Fig. 8. Values of MER range from a maximum of $1.2 \times 10^{6} \mathrm{~kg} / \mathrm{s}$ during the first week of May (from 4 to 9 May) down to $\sim 5.7 \times 10^{5} \mathrm{~kg} / \mathrm{s}$ after 19 May, just before the end of the eruption. The averaged value over the whole considered period is $\sim 8.7 \times 10^{5} \mathrm{~kg} / \mathrm{s}$. This average MER ranges between $\sim 6.0 \times 10^{5} \mathrm{~kg} / \mathrm{s}$ and $\sim 1.1 \times 10^{6} \mathrm{~kg} / \mathrm{s}$ assuming a radius of 20 and $30 \mathrm{~m}$, respectively. Moreover, if we consider the velocities $(u)$ derived by the assumption of a monopole (Fig. 7a) or quadrupole (Fig. 7c) source, the average MER during the same May 4-May 21 period changes by more than one order of magnitude, between $1.3 \times 10^{5} \mathrm{~kg} / \mathrm{s}$ and $2.9 \times 10^{6} \mathrm{~kg} / \mathrm{s}$.

\section{Determination of plume height and validation of results}

Determination of MER is vital for modeling plume dynamics, ash dispersal in the atmosphere, and final tephra sedimentation. Unfortunately, the existing methodologies to measure this key ESP are still controversial (e.g. Mastin et al., 2009; Degruyter and Bonadonna, 2012). Acoustic-derived velocities and MER should ideally be validated against other independent direct observations. Unfortunately, such a direct comparison is impossible due to the lack of alternative direct measurement techniques. For this reason we performed an indirect validation comparing the acoustic-derived MER with the one empirically derived from plume height measurements (Mastin et al., 2009).

\subsection{Plume height radar measurements}

Plume height during the eruption was monitored by IMO C-band weather radar located in Keflavík International Airport, at $155 \mathrm{~km}$ distance from the volcano (Arason et al., 2011). The radar provided 5 min plume altitudes with a minimum detection height of $2.5 \mathrm{~km}$ (a.s.l.), because of mountain ranges and curvature of the Earth, and a step resolution of $1.3 \mathrm{~km}$ (Oddsson et al.,
2012). Here we use hourly-averaged values of the heights provided by IMO assuming a minimum altitude of $2.5 \mathrm{~km}$ (a.s.l.) when the plume was not detected by radar. The hourly-averaged plume heights range from less than 4 up to $8 \mathrm{~km}$ (a.s.l.) during the considered period (Fig. 8). A comparison of the plume height evolution with the MER shown in Fig. 8 clearly indicates that the oscillations in plume height are not correlated with variations in the MER calculated by our acoustic approach (i.e. the peaks observed in plume height during 16-17 May have no counterpart in terms of acoustic MER, which is quite low during this interval).

This indicates that in the case of the Eyjafjallajökull eruption there is no direct correlation between amplitude of acoustic pressure and plume height.

\subsection{Theoretical and empirical relations}

Typically, MER is obtained from plume heights (and vice versa) based on theoretical and field-based empirical relationships (e.g., Wilson et al., 1978; Wilson and Walker, 1987; Sparks, 1986; Carey and Bursik, 2000; Sparks et al., 1997; Mastin et al., 2009). In particular, Mastin et al. (2009) considered 28 recent eruptions and obtained an empirical trend, regardless of eruption dynamics and magma composition and temperature, to estimate the volumetric flow rate $\dot{V}\left(\mathrm{~m}^{3} / \mathrm{s}\right.$ DRE):

$\dot{V}=0.0563 H^{4.15}$

from the plume height $H$ in $\mathrm{km}$, but with a scatter in the data that can vary this correlation of a factor of four in either direction. Such a scatter limits the accuracy in the calculation of MER from plume height and could be due to many reasons, including the uncertainty in estimates of both erupted mass and plume height, combination of plumes with different dynamics (e.g. buoyancy, wind-plume interaction) and combination of different atmospheric features (e.g. dry versus wet atmosphere). More recently Degruyter and Bonadonna (2012) have shown that the estimate of MER (and therefore of ash concentration in the atmosphere) from the equation of Mastin et al., (2009) is within a factor of ten with respect to a $1 \mathrm{D}$ model.

The comparison of Eq. (6) with the acoustic derived MER (Eq. (5)) at Eyjafjallajökull leads to substantial discrepancies (Fig. 8). MER derived from the plume height measured by the IMO radar peaks at $3.3 \times 10^{5} \mathrm{~kg} / \mathrm{s}$ on May 14 when plume height reaches $\sim 8 \mathrm{~km}$ above the sea level and its average value during the 4-21 May period is more than one order of magnitude smaller $\left(3.9 \times 10^{4} \mathrm{~kg} / \mathrm{s}\right)$ than MER derived by acoustic pressure using Eq. (5). Besides the two MERs show divergent fluctuation in time.

Empirical fit of Eq. (6) uses data mainly from strong plume eruptions and is consistent with the theoretical Buoyant Plume Theory (BPT) and scaling laws (Morton et al., 1956), which predict $\dot{V} \propto H^{4}$. For strong plumes, the drag forces are negligible and thus the entrainment velocity (the rate at which air enters the plume surface) is proportional to the plume vertical velocity (Turner, 1973). In contrast, self-induced turbulence dominates the initial stage of the rise of weak plumes because the velocity shear is nearly perpendicular to the plume axis, rather than parallel to it, which enhances turbulent mixing (Briggs, 1969). As a result, empirical and theoretical correlations between plume height and MER validated for strong plumes cannot be directly applied to weak plumes, such as the long-lasting plume associated with the Eyjafjallajökull eruption (e.g. Bursik, 2001; Bursik et al., 2012; Degruyter and Bonadonna, 2012).

\subsection{Buoyant plume theory model}

This apparent inconsistency can be explained by taking into account the effects of wind on the plume, a phenomenon typical 


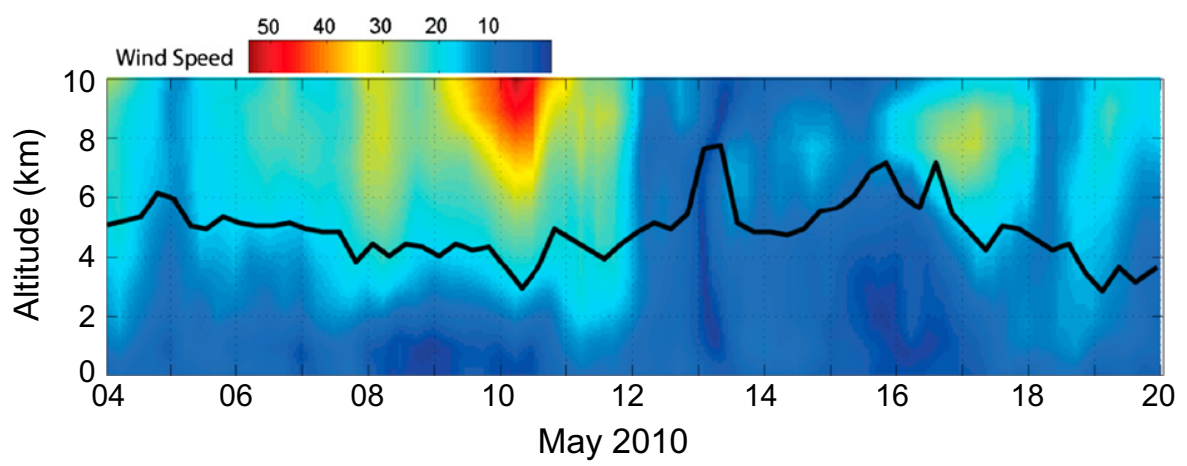

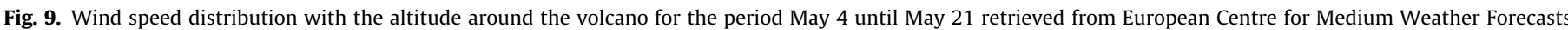

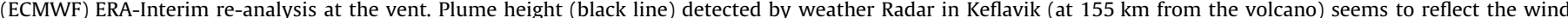
profile, reaching the maximum heights of $8 \mathrm{~km}$ during May 13-17 only when the wind intensity decreases below $10 \mathrm{~m} / \mathrm{s}$ over the whole $10 \mathrm{~km}$ high altitude profile.

in weak plumes. In fact, the overlap of local wind intensity and plume height reveals a good correlation between peaks of plume height and periods of low winds (Fig. 9).

Plume height and MER for weak bent-over plumes can be better described based on the radially averaged BPT equations (Woods and Bunik, 1991; Bursik, 2001; Mastin, 2007). Given the hourly values of acoustic-derived source velocity and MER (Eq. (5)), we used a BPT model accounting for plume bent-over in a cross-wind (Bursik, 2001; Carazzo et al., 2006, 2008) to estimate the evolution of the column height. Ambient conditions, necessary to solve the BPT equations, were supplied interpolating wind field and temperature profiles from the European Centre for Medium-Range Weather Forecasts (ECMWF) re-analysis ERA-Interim data archive (Dee et al., 2011) at $1.5^{\circ}$ horizontal resolution and 37 vertical pressure levels, at the vent coordinates, and covering from 1979 onward. Tephra particle properties, necessary to compute the particle terminal fall velocities in the BPT model, were derived from a reconstructed TGSD combining proximal ground observations (from 2 to $56 \mathrm{~km}$ ) and MSG-SEVIRI imagery (Bonadonna et al., 2011b). For the BPT simulations we considered 14 particle classes ranging from $4 \mathrm{~mm}$ to $0.5 \mu \mathrm{m}$ in diameter, and a density of $2740 \mathrm{~kg} / \mathrm{m}^{3}$, for particles smaller than $0.5 \mathrm{~mm}$, linearly decreasing down to $900 \mathrm{~kg} / \mathrm{m}^{3}$ for the rest of the granulometric spectrum (data from Bonadonna et al., 2011b).

Results of the BPT modeling using the acoustic-derived MER data are shown in Fig. 10. The advantage of this approach is that BPT-based plume height (red line in Fig. 10) can account for windinduced plume bent-over effect. In fact, BPT-acoustic plume height is comparable to and follows the variations of plume height observed by the IMO radar (black line in Fig. 10). This good fit between calculated and measured plume height is not achieved when the MERs derived from considering an acoustic monopole and quadrupole source are used (lower and upper dashed blue lines, respectively, in Fig. 10). This result seems to support the choice of the acoustic dipole source.

It is noteworthy, that the range of uncertainty on the vent radius (between 20 and $30 \mathrm{~m}$ ) is affecting the estimate on the plume height of less than $12 \%$, which corresponds to $900 \mathrm{~m}$ over $7 \mathrm{~km}$. This is less than the $21 \%$ of resolution of the weather C-band Doppler radar located in Keflavik, which at $155 \mathrm{~km}$ of distance from the volcano has an uncertainty of $1.3 \mathrm{~km}$ (Oddsson et al., 2012).

\section{Discussion and conclusions}

The Eyjafjallajökull 2010 eruption demonstrated well the vulnerability of our globalized society to even moderate explosive volcanic eruptions. Nonetheless, the Eyjafjallajökull 2010

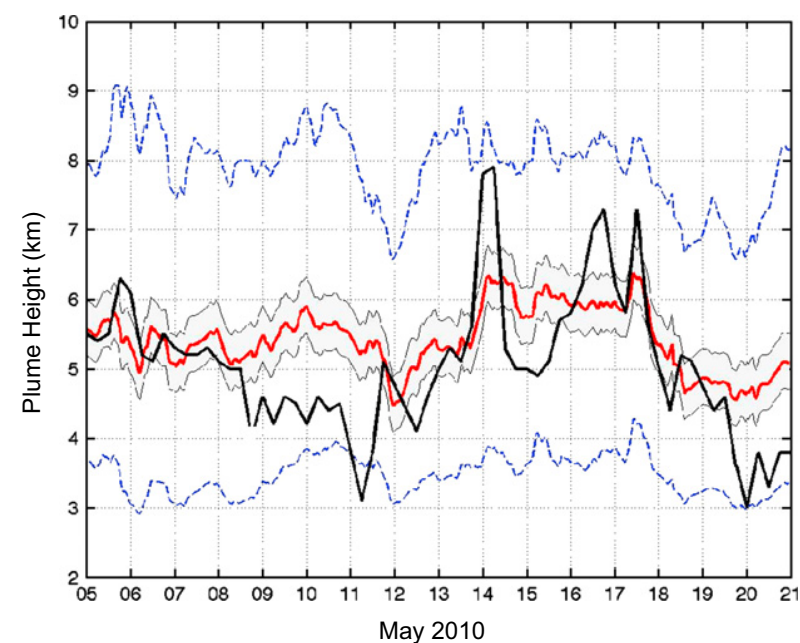

Fig. 10. Plume height from Keflavik's Radar (black line) is compared with the plume height modeling the MER derived from acoustic by using the radially averaged BPT equations. The BPT modeling has been applied to time dependent MER (Eq. (5)) calculated for a vent diameter of $50 \mathrm{~m}$ (red line) $\pm 10 \mathrm{~m}$ (gray band) and considering the wind field and temperature profiles from the ERA-Interim reanalysis at the vent (Fig. 9). Vent dimension is changing plume height for only $\pm 450 \mathrm{~m}$, whereas using the velocities derived from the monopole (lower blue dashed line) and quadrupole (upper blue dashed line) acoustic sources (Eqs. (2a and $2 \mathrm{c})$ ) the plume height fluctuates between $3-4 \mathrm{~km}$ and 7-9 km, respectively. The difference (from 8 to 11 May, and 21 May) between the Radar (black line) and the acoustic derived (red lines) plume heights can be explained in terms of both an overestimation of the MER calculated by acoustics (Eq. 5) or an underestimation of the plume height by the Radar in Keflavik due to bad weather conditions and/or to the $1.3 \mathrm{~km}$ step resolution. (For interpretation of the references to colour in this figure legend, the reader is referred to the web version of this article.)

eruption represented an exceptional turning point in modern volcanology having produced a tremendous amount of ground and remote sensing data with the potential of revolutionizing the way real-time forecasting will be approached in the future. All this information also provides an amazing opportunity to improve our understanding of both geophysical monitoring and plume dynamics.

\subsection{Plume dynamics and mass eruption rate}

Even though the Eyjafjallajökull plume was sustained for about 40 days, the source dynamics revealed intermittent activity. In fact, both our thermal image analysis and acoustic signals show that plume oscillations are better described by the continuous occurrence of puffs, which injected hot ash and gas in the atmosphere every $20 \mathrm{~s}$ and reached heights up to $\sim 2 \mathrm{~km}$ above sea level. Material was ejected during a few seconds ( $\sim 5-6 s)$ and 
reached the velocity of $20-150 \mathrm{~m} / \mathrm{s}$ within the first $2 \mathrm{~s}$. Then puffs rose at the buoyancy speed of $\sim 10-20 \mathrm{~m} / \mathrm{s}$ during the following $\sim 3-4 \mathrm{~s}$. A pulsating eruptive behavior at source has already been observed during other volcanic eruptions of various magma compositions (e.g. Ruapehu, Bonadonna et al., 2005; Cerro Negro, Hill et al., 1998; Etna, Vergniolle and Ripepe, 2008 and Andronico et al., 2008; Stromboli, Ripepe et al., 1993). Nonetheless, when the interval between pulses is significantly smaller than the cumulative time required by individual puffs to reach their final height, a sustained volcanic plume is generated, whose dynamics can be described with classic BPT (e.g. Fig. 10).

Plume velocity measured by thermal analysis allows us to discriminate amongst monopole, dipole and quadrupole acoustic sources and to convert pressure into exit velocity.

The acoustic dipole source has already been used to model the infrasound of other volcanoes (e.g. Vergniolle and CaplanAuerbach, 2006; Johnson et al., 2008; Kim et al., 2012) but we have no clear evidence based on acoustic wavefield directivity to support this assumption. Vulcanian explosions at Tungurahua volcano (Ecuador) show an amplitude distribution consistent with the directivity of a horizontally-oriented dipole source combined with a small monopole source component (Kim et al., 2012). This observation seems to support our acoustic dipole source but it is also pointing out the possibility to have an anisotropy distribution of the acoustic amplitude around the crater. In other words, amplitude of acoustic signals recorded by a single station could be underestimated (or overestimated) according to the degree of directivity of the dipole wavefield. The interaction of the topography in the near source could reduce acoustic amplitude leading to an error in estimating MER from acoustic pressure (Lacanna and Ripepe, 2013) and then should be also considered in future application. However, the amplitude ratio in the $0.02-0.5 \mathrm{~Hz}$ frequency band between the acoustic pressure (Fig. 6) recorded at station YHL and at the array EJA, at 10.6 and $8.3 \mathrm{~km}$ respectively, is $\sim 1.3$ which is compatible with the ratio (1.27) between the distances of both stations from the crater (Fig. 1a). This suggests that the effect of dipole directivity and/or topography at Eyjafjallajökull in this frequency range is small or that contrary to what is observed at Tungurahua, ash eruption can be represented by a near vertical dipole source. This observation indicates that the MER calculated from acoustic signals is independent of the position of the station relative to the crater.

Moreover, acoustics and thermal analysis indicate that the plume was sustained by repeating impulses of ash driven out the vent at velocities ranging between 54 and $152 \mathrm{~m} / \mathrm{s}$ (average of $75 \mathrm{~m} / \mathrm{s}$ ). The advantage of acoustic data over thermal imagery is that acoustic data was available continuously during most part of the eruption (5-21 May 2010), and, therefore, MER could be calculated over a large period of time. In particular, we calculate a maximum discharge rate of $1.2 \times 10^{6} \mathrm{~kg} / \mathrm{s}$ during the first week of May (from 4 to 7 May), which is in line with the maximum discharge rate of $0.9 \times 10^{6} \mathrm{~kg} / \mathrm{s}$ calculated by integrating information from tephra fallout maps with plume height (Gudmundsson et al., 2012) value of $\sim 3.1 \times 10^{6} \mathrm{~kg} / \mathrm{s}$ based on ensemble plume modeling for the first violent explosive phase from 14 to 18 April (Bursik et al., 2012). Our average discharge rate of $\sim 8.7 \times 10^{5} \mathrm{~kg} / \mathrm{s}$ for the period 4-21 May is also in agreement with the groundbased mean $\sim 10^{5} \mathrm{~kg} / \mathrm{s}$ MER derived by Bonadonna et al. (2011b) and the MER range of $0.1-5.0 \times 10^{6} \mathrm{~kg} / \mathrm{s}$ derived by the theoretical equation of Degruyter and Bonadonna (2012) for the period 4-8 May. Other estimates of MER during different phases of the Eyjafjallajökull eruption include $7.5 \times 10^{5} \mathrm{~kg} / \mathrm{s}$ with $\pm 50 \%$ uncertainty for the first explosive phase (14-16 April) (Schumann et al. 2010), $10^{4} \mathrm{~kg} / \mathrm{s}$ for $18-30$ April and $1-5 \times 10^{4} \mathrm{~kg} / \mathrm{s}$ for $1-4$ May (Petersen 2010), which are derived by the plume height using the empirical Eq. (6) and one order of magnitude smaller than our estimate.

\subsection{Implications for ESP characterization and real-time plume dispersal forecasting}

Downwind ash concentrations predicted by dispersal models critically depend on ESP (mainly plume height, MER, and TGSD), which are often difficult to determine in real time with the necessary accuracy (Bonadonna et al., 2011a; Mastin et al., 2009).

Ash concentration and total mass erupted during a given eruptive interval directly depend on MER which, in operational mode, is typically inferred from plume height observations (e.g., Mastin et al., 2009; Sparks et al., 1997). Plume height can be determined in near real time based on satellite retrievals, ground-based instrumentation (e.g., radar, lidar, and thermal cameras), and direct visual observations. However, multiple shortcomings exist. Plume height estimates are affected by a certain degree of uncertainty related to many factors, such as bad weather conditions, low frequency of satellite passages, and poor vertical resolution in the case of radar observation (see, e.g., Oddsson et al., 2012; Prejean and Brodsky, 2011; Sigmundsson et al., 2012), resulting in plume heights differing by up to several kilometers from each other. Second, empirical relations linking plume height and MER are characterized by a significant scatter, that can result in a variation on MER within ten orders of magnitude (e.g. Degruyter and Bonadonna, 2012; Mastin et al., 2009), with strong impact on the forecasted ash concentration and erupted mass. Third, when inferring MER from plume heights, uncertainties are highly amplified due to the associated power-4 relationship (for example, for a plume of $10 \mathrm{~km}$ height, a simple $20 \%$ underestimation in the measurement of height results in a MER nearly 2.5 times lower). Finally, most existing theoretical/empirical relations that link MER and plume height do not rigorously take into account critical meteorological data (e.g., humidity and wind speed), and are based on a general direct proportionality between the two parameters, i.e. a lower plume will always be associated with a lower MER and vice versa. Nonetheless, meteorological data, in particular humidity and surrounding wind field (Bursik, 2001; Mastin, 2007), can significantly affect the rise of weak plumes, for which classical MER-Plume Height relations are more uncertain (Bursik et al., 2012; Degruyter and Bonadonna, 2012). As an example, Eyjafjallajökull plume heights detected by the IMO Doppler radar in Keflavik do not mimic the peaks in MER underlined by acoustics, with the plume height being the lowest when the wind was strongest (e.g. 11 May, 2010) and the highest when the wind was the weakest (e.g. 14 May, 2010) (Fig. 9). This demonstrates how, for a given MER, plume height can oscillate depending on the intensity of the wind.

Here we propose an alternative strategy for the determination of MER based on the assumption that acoustic pressure is related to the exit velocity of the eruptive mixture, which can be converted into MER. Clearly, these assumptions require further investigations but, nonetheless, the integration between acoustic pressure and BPT modeling using atmospheric profiles near the source is very promising. The implications of our results are twofold. First, MER could be related to the height of weak plumes only if based on theoretical and/or numerical formulations that account for meteorological conditions (e.g. BPT). Second, due to the power- 4 relation between MER and plume height, the uncertainty in the calculation of MER is reduced if directly related to the source dynamics even in the case of strong plumes. 
Although our results at Eyjafjallajökull are encouraging, it should be noted that a better understanding of infrasonic signals is necessary before using efficiently this technique in quasi-realtime (Caplan-Auerbach and McNutt, 2003). During the explosive phase of the $2006 \mathrm{Mt}$. Augustine eruption (January 11-28), plume heights of 13 individual events exhibited no apparent correlation with the corresponding acoustic pressures (Petersen et al., 2006). In this sense, infrasonic signals related to small ash-rich Vulcanian explosions at Sakurajima volcano (Japan) show a wide variation of plume height (Tupper et al., 2003). This indicates that a direct correlation between acoustic pressure and plume height is not always possible without considering the interaction between the plumes and the atmosphere. Part of this variation can be explained as due to the different atmospheric conditions (e.g., wind speed and humidity) affecting the plume dynamics, and hence the resulting height, and in part also to propagation effects of the infrasonic waves at a regional scale. However, infrasounds produced by sub-Plinian and Plinian eruptive activity at Tungurahua volcano (Ecuador) and recorded at two infrasonic arrays located at regional distance ( 40 and $210 \mathrm{~km}$ ) from the sources show a good correlation between the increase of acoustic energy and the height of the ash cloud observed by satellite (Garces et al., 2008; Fee et al., 2010). Consistently, infrasonic signals recorded by the IMS network show that the maximum distance of detection (up to $\sim 10,000 \mathrm{~km}$ ) scales with the eruption intensity and the plume height (Dabrowa et al., 2011). Despite the scatter in the data, these empirical correlations indicate the physical link between the acoustic amplitude and the height of the eruptive plume.

Our work is presenting evidence that this correlation between acoustic pressure and plume height exists also for weak plume eruption but only if atmospheric conditions at the vent are considered and it is proposing a new way of constraining plume MER (a crucial ESP) that has the potential of revolutionizing the real-time detection of erupted mass during volcanic crisis.

\section{Acknowledgments}

We want to thank Riccardo Genco, Marco Pistolesi, Raffaello Cioni, Antonella Bertagnini, and Martin Henshe for their help in the field during the Eyjafjallajökull eruption. M.R., D.D.D., G.L. and E.M. have been funded by the Italian AshErupt PRIN project, the Italian Civil Protection and the ARISE EC project; A.F. by the Spanish National ATMOST project (No. CGL2009-10244); and C.B. by a Fond National Suisse project (No. 200020-125024). This work has been largely improved by the critical comments of two anonymous referees.

\section{References}

Andronico, D., Scollo, S., Caruso, S., Cristaldi, A., 2008. The 2002-03 Etna explosive activity: tephra dispersal and features of the deposits. J. Geophys. Res. 113, B04209, http://dx.doi.org/10.1029/2007JB005126.

Arason, P., Petersen, G.N., Bjornsson, H., 2011. Observations of the altitude of the volcanic plume during the eruption of Eyjafjallajökull, April-May 2010. Earth Syst. Sci. Data 3, 9-17.

Bonadonna, C., Phillips, J.C., Houghton, B.F., 2005. Modeling tephra fall from a Ruapehu weak plume eruption. J. Geophys. Res. 110 (B08209), http://dx.doi. org/10.1029/2004JB003515.

Bonadonna, C., Folch, A., Loughlin, S., Puempel, H., 2011a. Future developments in modeling and monitoring of volcanic ash clouds: outcomes from the first IAVCEI-WMO workshop on Ash Dispersal Forecast and Civil Aviation. Geneva, Switzerland, 18-20 October 2010, Short Scientific Communication, Bull. Volcan.

Bonadonna, C., Genco, R., Gouhier, M., Pistolesi, M., Cioni, R., Alfano, F., Hoskuldsson, A., Ripepe, M., 2011b. Tephra sedimentation during the 2010 Eyjafjallajökull eruption (Iceland) from deposit, radar, and satellite observations. J. Geophys. Res. 116, B12202, http://dx.doi.org/10.1029/2011JB008462.
Borisova, A.Y., Toutain, J.P., Stefansson, A., Gouy, S., de Parseval, P., 2012. Processes controlling the 2010 Eyjafjallajökull explosive eruption. J. Geophys. Res. 117 B05202, http://dx.doi.org/10.1029/2012JB009213.

Briggs, G.A., 1969. Optimum formulas for buoyant plume rise. Philos. Trans. R. Soc London 265, 97-203.

Bursik, M., 2001. Effect of wind on the rise height of volcanic plumes. Geophys. Res. Lett. 28, 3621-3624.

Bursik, M., Jones, M., Carn, S., Dean, K., Patra, A., Pavolonis, M., Pitman, E.B. Singh, T., Singla, P., Webley, P., Bjornsson, H., Ripepe, M., 2012. Estimation and propagation of volcanic source parameter uncertainty in an ash transport and dispersal model: application to the Eyjafjallajökull plume of 14-16 April 2010. Bull. Volcanol., http://dx.doi.org/10.1007/s00445-0120665-2.

Campus, P., Christie, D.R., 2010. Worldwide observations of infrasonic waves. In: Le Pichon, A., Blanc, E., Hauchecorne, A. (Eds.), Infrasound Monitoring for Atmospheric Studies. Springer, Netherlands, pp. 185-234.

Caplan-Auerbach, J., Bellesiles, A., Fernandes, J.K., 2009. Estimates of eruption velocity and plume height from infrasonic recordings of the 2006 eruption of Augustine Volcano, Alaska. J. Volcanol. Geotherm. Res. 189, 12-18.

Caplan-Auerbach, J.S., McNutt, R., 2003. New insights into the 1999 eruption of Shishaldin volcano, Alaska, based on acoustic data. Bull. Volcanol. 65, 405-417, http://dx.doi.org/10.1007/s00445-002-0267-5.

Carazzo, G., Kaminski, E., Tait, S., 2008. On the dynamics of volcanic columns: a comparison of field data with new model of negatively buoyant jets. J. Volcanol. Geotherm. Res. 178, 94-103.

Carey, S., Sparks, R.S.J., 1986. Quantitative models of the fallout and dispersal of tephra from volcanic eruption columns. Bull. Volcanol. 48, 109-125.

Carey, S., Bursik, M., 2000. Volcanic plumes. In: Sigurdson, H., et al. (Eds.), Encyclopedia of Volcanoes. Academic, San Diego, Calif, pp. 527-554.

Coelho, S.L.V., Hunt, J.C.R., 1989. The dynamics of the near-field of strong jets in cross-flows. J. Fluid Mech. 200, 95-120.

Dabrowa, A.L., Green, D.N., Rust, A.C., Phillips, J.C., 2011. A global study of volcanic infrasound characteristics and the potential for long-range monitoring. Earth Planet. Sci. Lett. 310 (2011), 369-379, http://dx.doi.org/10.1016/ j.epsl.2011.08.027.

Dee, D.P., et al., 2011. The ERA-Interim reanalysis: configuration and performance of the data assimilation system. Q. J. R Meteorolog. Soc. 137 (656), 553-597, http://dx.doi.org/10.1002/qj.828.

Degruyter, W., Bonadonna, C., 2012. Improving on mass flow rate estimates of volcanic eruptions. Geophys. Res. Lett., http://dx.doi.org/10.1029/2012GL052566.

Delle Donne, D., Ripepe, M., 2012. High-frame rate thermal imagery of Strombolian explosion: implication of infrasonic source dynamics. J. Geophys. Res. 117 B09206, http://dx.doi.org/10.1029/2011JB008987.

Ernst, G.G.J., Davis, J.P., Sparks, R.S.J., 1994. Bifurcation of volcanic plumes in crosswind. Bull. Volcanol. 56 (3), 159-169, http://dx.doi.org/10.1007/ BF00279601.

Fee, D., Garces, M.A., Steffke, A., 2010. Infrasound from Tungurahua volcano 20062008: Strombolian to Plinian Eruptive activity. J. Volcanol. Geotherm. Res. 193 (1-2), 67-81, http://dx.doi.org/10.1016/j.jvolgeores.2010.03.006.

Garces, M., Fee, D., Steffke, A., McCormack, D.P., Servranckx, R., Bass, H., Hetzer, C., Heldin, M., Matoza, R.S., Yepes, H., Ramon, P., 2008. Capturing the acoustic fingerprint of stratospheric ash injection. Eos Trans. Am. Geophys. Union 89 (40).

Gudmundsson, M.T., Thordarson, T., Hoskuldsson, A., Larsen, G., Bjornsson, H., Prata, F.J., Oddsson, B., Magnusson, E., Hognadottir, T., Petersen, N., Hayward, C.L., Stevenson, J.A., Jónsdóttir, I., 2012. Ash generation and distribution from the April-May 2010 eruption of Eyjafjallajökull, Iceland. Sci. Rep. 2 (572), http://dx.doi.org/10.1038/srep00572.

Guffanti, M., Casadevall, T.J., Budding, K., 2010. Encounters of aircraft with volcanic ash clouds: a compilation of known incidents, 1953-2009: US Geological Survey Data Series 545, ver. 1.0, 12 p., plus appendixes.

Hill, B.E., Connor, C.B., Jerzemba, M.S., La Femina, P.C., Navarro, M., Strauch, W., 1998. 1995 eruptions of Cerro Negro volcano, Nicaragua and risk assessment for future eruptions. Geol. Soc. Am. Bull. 110, 1231-1241.

Johnson, J.B., 2007. On the relation between infrasound, seismicity, and small pyroclastic explosions at Karymsky Volcano. J. Geophys. Res. 112 (B08203) http://dx.doi.org/10.1029/2006/JB004654 2007.

Johnson, J.B., Aster, R., Jones, K., Kyle, P., McIntosh, B., 2008. Acoustic source characterization of impulsive strombolian eruptions from the Mount Erebus lava lake. J. Volcanol. Geotherm. Res. 177 (3), 673-686.

Johnson, J.B., Ripepe, M., 2011. Volcano infrasound: a review. J. Volcanol Geotherm. Res. 206 (3-4), 61-69.

Kim, K., Lees, J.M., Ruiz, M., 2012. Acoustic multipole source model for volcanic explosions and inversion for source parameters. Geophys. J. Int. 191 (3), 1192-1204, http://dx.doi.org/10.1111/j.1365-246X.2012.05696.x.

Lacanna, G., Ripepe, M., 2013. Influence of near-source volcano topography on the acoustic wavefield and implication for source modeling. J. Volcanol. Geotherm. Res. 250 (2013), 9-18, http://dx.doi.org/10.1016/j.jvolgeores.2012.10.005

Le Pichon, A., Blanc, E., Drob, D., Lambotte, S., Dessa, J.X., Lardy, M., Bani, P., Vergniolle, S., 2005. Infrasound monitoring of volcanoes to probe high-altitude winds. J. Geophys. Res. 110, D13106.

Lighthill, M.J., 1978. Waves in Fluids. Cambridge University Press, New York, pp. 504

Marchetti, E., Ripepe, M., Harris, A.J.L., Delle Donne, D., 2009. Tracing the differences between Vulcanian and Strombolian explosions using infrasonic and thermal radiation energy. Earth Planet. Sci. Lett. 279, 273-281, http://dx.d oi.org/10.1016/j.epsl.2009.01.004. 
Mastin, L.G., 2007. A user-friendly one-dimensional model for wet volcanic plumes. Geochem. Geophys. Geosyst. 8, Q03014, http://dx.doi.org/10.1029/ 2006 GC001455.

Mastin, L., Guffanti, M., Servanckx, R., Webley, P., Barostti, S., Dean, K., Denlinger, R. Durant, A., Ewert, J., Gardner, C., Holliday, A., Neri, A., Rose, W., Schneider, D. Siebert, L, Stunder, B., Swanson, G., Tupper, A, Volentik, A., Waythomas, A. 2009. A multidisciplinary effort to assign realistic source parameters to models of volcanic ash-cloud transport and dispersion during eruptions. J. Icanol. Geotherm. Res. 186, 10-21, special issue on Volcanic Ash Clouds; Mastin, L., Webley, P.W. (Eds.)..

Matoza, R., Fee, D., Garces, M., Seiner, J.M., Ramon, P.A., Hedlin, M.A.H., 2009 Infrasonic jet noise from volcanic eruptions. Geophys. Res. Lett. 36, L08303.

Matoza, R.S., Le Pichon, A., Vergoz, J., Herry, P., Lalande, J.M., Lee, H.I., Che, I.Y., Rybin, A., 2011a. Infrasonic observations of the June 2009 Sarychev Peak eruption, Kuril Islands: implications for infrasonic monitoring of remote explosive volcanism. J. Volcanol. Geotherm. Res 200, 35-48.

Matoza, R.S., Vergoz, J., Le Pichon, A., Ceranna, L., Green, D.N., Evers, L.G., Ripepe, M. Campus, P., Liszka, L., Kvaerna, T., Kjartansson, E., Hoskuldsson, A., 2011b. Longrange acoustic observations of the Eyjafjallajökull eruption, Iceland, April-May 2010. Geophys. Res. Lett. 38, L06308.

McNutt, S.R., 2004. Volcanic tremor and its use in estimating eruption parameters. In: Proceedings of the 2nd International Conference on Volcanic Ash and Aviation Safety, US Department of Commerce, NOAA, Section 2, p. 49-50.

Miller, S.A., 2011. April 2010 UK Airspace closure: experience and impact on the UK's air-travelling public and implications for future travel. J. Air Transp. Manage. 17 (5), 296-301.

Miller, T.P., Casadevall, T.J., 2000. Volcanic ash hazards to aviation. In: Sigurdsson, H., Houghton, B.F., McNutt, S.R., Rymer, H., Stix, J. (Eds.), Encyclopedia of Volcanoes. Academic Press, San Diego, pp. 915-930.

Morton, B.R., Taylor, G.I., Turner, J.S., 1956. Turbulent gravitational convection from maintained and instantaneous sources. Proc. R. Soc. London A 234 (1196), 1-23, http://dx.doi.org/10.1098/rspa.1956.0011.

Nishimura, T., 1995. Source parameters of the volcanic eruption earthquakes at Mount Tokachi, Hokkaido, Japan, and a magma ascending model. J. Geophys. Res. 100 (B7), 12465-12473, http://dx.doi.org/10.1029/95JB00867.

Nishimura, T., McNutt, S.R., 2008. Volcanic tremor during eruptions: tempora characteristics, scaling and estimates of vent radius. J. Volcanol. Geotherm. Res. 178, 10-18.

O'Regan, M., 2011. On the edge of chaos: European aviation and disrupted mobilities. Mobilities 6 (1), 21-30.

Oddsson, B., Gudmundsson, M.T., Larsen, G., Karlsdóttir, S., 2012. Monitoring of the plume from the basaltic phreatomagmatic 2004 Grímsvötn eruption-application of weather radar and comparison with plume models. Bull. Volcanol., http://dx.doi.org/10.1007/s00445-012-0598-9.

Petersen, T., De Angelis, S., Tytgat, G., McNutt, S.R., 2006. Local infrasound observations of large ash explosions at Augustine Volcano, Alaska, during January 11-28, 2006. Geophys. Res. Lett. 33, L12303.

Petersen, G.N., 2010. A short meteorological overview of the Eyjafjallajökul eruption 14 April-23 May 2010. Weather 65, 203-207.

Prata, A.J., Tupper, A., 2009. Aviation hazards from volcanoes: the state of the science,. Nat. Hazards, http://dx.doi.org/10.1007/s11069-009-9415-y.

Prejean, S.G., Brodsky, E.E., 2011. Volcanic plume height measured by seismic waves based on a mechanical model. J. Geophys. Res. 116, B01306, http://dx.d oi.org/10.1029/2010JB007620.

Ripepe, M., Marchetti, M., 2002. Array tracking infrasonic sources at Stromboli volcano. Geophys. Res. Lett. 29 (22), 331-334.

Ripepe, M., Rossi, M., Saccorotti, G., 1993. Image analysis of the dynamical behavior at Stromboli. J. Volcanol. Geotherm. Res. 54, 335-351.

Ripepe, M., Harris, A.J.L., Carniel, R., 2002. Thermal, seismic and infrasonic evidences of variable degassing rates at Stromboli volcano. J. Volcanol. Geotherm. Res. 118, 285-297.

Rose, W.I., Delene, D.J., Schneide, D.J., Bluth, G.J.S., Krueger, A.J., Sprod, I., McKee, C. Davies, H.L., Ernst, G.G.J., 1995. Ice in the 1994 Rabaul eruption cloud: implications for volcano hazard and atmospheric effects. Nature 375, 477-479, http://dx.doi.org/10.1038/375477a0.
Schumann, U., Weinzierl, B., Reitebuch, O., Schlager, H., Minikin, A., Forster, C., Baumann, R., Sailer, T., Graf, K., Mannstein, H., Voigt, C., Rahm, S., Simmet, R., Scheibe, M., Lichtenstern, M., Stock, P., Rüba, H., Schäuble, D., Tafferner, A. Rautenhaus, M., Gerz, T., Ziereis, H., Krautstrunk, M., Mallaun, C., Gayet, J.-F., Lieke, K., Kandler, K., Ebert, M., Weinbruch, S., Stohl, A., Gasteiger, J., Olafsson, H., Sturm, K., 2010. Airborne observations of the Eyjafjalla volcano ash cloud over Europe during air space closure in April and May 2010. Atmos. Chem. Phys. Discuss. 10, 22131-22218, http://dx.doi.org/10.5194/acpd-1022131-2010.

Scollo, S., Prestifilippo, M., Spata, G., Agostino, M.D, Coltelli, M., 2009. Monitoring and forecasting Etna volcanic plumes. Nat. Hazards Earth Syst. Sci. 9, 1573-1585.

Sigmundsson, F., Hreinsdóttir, S., Hooper, A., Árnadóttir, T., Pedersen, R., Roberts, M. Óskarsson, N., Auriac, A., Decriem, J., Einarsson, P., Geirsson, H., Hensch, M., Ófeigsson, B.G., Sturkell, E., Sveinbjörnsson, H., Feigl, K.L., 2010. Intrusion triggering of the 2010 Eyjafjallajökull explosive eruption. Nature 468, 426-430, http://dx.doi.org/10.1038/nature09558.

Sigmundsson, F., Hreinsdottir, S., Bjornsson, H., Arason, P., Grapenthin, R., Roberts, M.J., Holmjarn, J., Geirsson, H., Arnadottir, T., Bennett, R.A., Oddsson, B., Gudmundsson, M.T., Ofeigsson, B.G., Villemin, T., Sturkell, E.C., 2012. Grímsvötn 2011 explosive eruption, Iceland: relation between magma chamber pressure drop inferred from high rate geodesy and plume strength from radar observations. In: Proceedings of the 30th Nordic Geological Winter Meeting, Reykjavík, 9-12 January 2012.

Sparks, R.S.J., 1986. The dimensions and dynamics of volcanic eruption columns. Bull. Volcanol. 48, 3-15.

Sparks, R.S.J., Bursik, M., Carey, S., Gilbert, J.S., Glaze, L.S., Sigurdsson, H., Woods, A.W. (Eds.), 1997. Volcanic Plumes. John Wiley, New York

Tupper, A., Kinoshita, K., Kanagaki, C., Iino, N., Kamada, Y., 2003. Observations of volcanic cloud heights and ash-atmosphere interactions. In: Proceedings of the WMO/ICAO Third International Workshop on Ulfarsson, G. F. and E. A. Unger (2011). "Impacts and Responses of Icelandic Aviation to the 2010 Eyjafjallajökull Volcanic Eruption Case Study.” Transportation Research Record (2214), pp. 144-151. Volcanic Ash, Toulouse, France, September 29-October 3, 2003.

Turner, J.S., 1973. Buoyancy effects in fluids. Cambridge University Press.

Ulfarsson, G.F., Unger, E.A., 2011. A case study of Icelandic aviation impacts and responses due to the 2010 Eyjafjallajökull volcanic eruption. Transportation Research Record: Journal of the Transportation Research Board, 2214, National Research Council, Washington, DC, USA, pp. 144-151.

Ulivieri, G., Marchetti, E., Ripepe, M., Chiambretti, I., De Rosa, G., Segor, V., 2011 Monitoring snow avalanches in Northwestern Italian Alps using an infrasound array. Cold Reg. Sci. Technol. 69 (2-3), 177-183, http://dx.doi.org/10.1016/ j.coldregions.2011.09.006

Vergniolle, S., Brandeis, G., Mareschal, J.C., 1996. Strombolian explosions: 2. Eruption dynamics determined from acoustic measurements. J. Geophys. Res. 101 (B9), 20449-20466.

Vergniolle, S., Caplan-Auerbach, J., 2006. Basaltic thermals and subplinian plumes: constraints from acoustic measurements at Shishaldin volcano, Alaska. Bull. Volcanol. 68, 611-630.

Vergniolle, S., Ripepe, M., 2008. From Strombolian explosions to fire fountains at Etna Volcano (Italy): what do we learn from acoustic measurements? Geol. Soc. London Spec. Publ. 307, 103-124.

Wilson, L., Sparks, R.S.J., Huang, T.C., Watkins, N.D., 1978. The control of volcanic column heights by eruption energetics and dynamics. J. Geophys. Res. 83, 1829-1836.

Wilson, L., Walker, G.P.L., 1987. Explosive volcanic eruptions: VI. Ejecta dispersal in plinian eruptions: the control of eruption conditions and atmospheric properties. Geophys. J. R. Astron. Soc. 89, 657-679.

Woods, A.W., Bunik, M.I., 1991. Particle fallout, thermal disequilibrium and volcanic plumes. Bull. Volcanol. 53, 559-570.

Woulff, G., McGetchin, T.R., 1976. Acoustic noise from volcanoes: theory and experiments. Geophys. J. R. Astron. Soc. 45, 601-616.

Wright, J.V., Roobol, M.J., Smith, A.L., Sparks, R.S.J., Brazier, S.A., Rose, W.I., Sigurdsson, H., 1984. Late Quaternary explosive silicic volcanism on St Lucia, West Indies. Geol. Mag. 121 (1), 1-15. 